\title{
Article \\ Development and Implementation of the Smart Village Concept as a Challenge for the Modern Power Industry on the Example of Poland
}

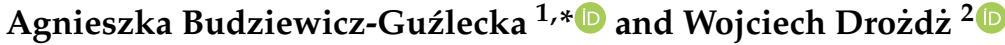 \\ 1 Institute of Spatial Management and Socio-Economic Geography, University of Szczecin, \\ 71-101 Szczecin, Poland \\ 2 Institute of Management, University of Szczecin, 71-101 Szczecin, Poland; wojciech.drozdz@usz.edu.pl \\ * Correspondence: agnieszka.budziewicz-guzlecka@usz.edu.pl
}

Citation: Budziewicz-Guźlecka, A.; Drożdż, W. Development and Implementation of the Smart Village Concept as a Challenge for the Modern Power Industry on the Example of Poland. Energies 2022, 15, 603. https://doi.org/10.3390/ en15020603

Academic Editor: Ben McLellan

Received: 12 December 2021

Accepted: 13 January 2022

Published: 15 January 2022

Publisher's Note: MDPI stays neutral with regard to jurisdictional claims in published maps and institutional affiliations.

Copyright: (c) 2022 by the authors. Licensee MDPI, Basel, Switzerland This article is an open access article distributed under the terms and conditions of the Creative Commons Attribution (CC BY) license (https:// creativecommons.org/licenses/by/ $4.0 /)$.

\begin{abstract}
Nowadays, while cities are often subject to research in terms of their development, especially smart development, studies on rural areas are rare. However, the development of the latter is very important. It is important that rural areas develop economically and socially. Smart villages are a challenge for the modern energy sector. The authors of the article try to answer the question: What are the challenges for the modern energy sector in the context of rural development? The aim of this article is to identify challenges for the modern power industry in the concept of smart countryside development. The article begins with the presentation of the essence of smart villages and the essence of energy policy. The research facilitated the identification of basic challenges that prevent or slow down the development of the smart villages in terms of modern energy solutions, as perceived by experts and residents, and farmers and entrepreneurs operating in rural areas. The article identifies a number of energy challenges in the context of a smart village. They include, among others, a lack of awareness regarding the impact of energy on the environment, a low level of public knowledge about new energy solutions, and a lack of social trust in modern energy solutions in rural areas. The research was conducted in rural areas in the north-western part of Poland. At the end, the article presents a model of rural development in the context of the modern energy sector. The research also allowed the creation of a smart village development model that focuses on smart economy, intelligent environment, intelligent people, and intelligent governance. Since these are universal solutions, they can be used as a proposition for other countries.
\end{abstract}

Keywords: smart village; energy policy; modern energy solutions

\section{Introduction}

Energy is used in all branches of the national economy. The efficient functioning of energy systems ensures energy-efficient products, and harmonious energy development is necessary to ensure the proper development of the entire economy, including the modern smart village. The aim of this article is to identify challenges for the modern power industry in the context of smart rural area development. The research facilitated the identification of basic challenges that prevent or slow down the development of the smart village in the area of modern energy solutions, as perceived by experts and residents, and farmers and entrepreneurs operating in rural areas.

The implementation of the national energy policy is a part of the state interest. The national energy policy (like other sectoral policies [1]) should meet political, economic, and social goals of the state and those of its citizens. The form of energy regulation varies greatly depending on the form of government and regime. The main imperative of the Polish energy doctrine is to ensure access to electricity and heat for all citizens and the economy, while maintaining acceptable energy prices, economic competitiveness, and at the same time maintaining a high level of energy security and independence $[2,3]$. The 
doctrine, due to external as well as internal factors, is currently subject to transformation, but its basic tenets have remained unchanged for several decades. These are:

- Use of national resources, such as hard coal and lignite deposits, which ensures one of the highest levels of energy independence in Europe and, consequently, a high level of energy security;

- Development of hard coal and lignite mining and effort to make it profitable;

- Generation based on coal, modernization, and replacement of worn-out generation units by new coal-fired power plants;

- Limited use of other sources of energy that act as a complement to the base load.

However, these factors have had to change due to the recent development. They include:

- EU membership since 2004 and the need to participate in and implement the EU energy policy whose main objective is to decarbonize member states' energy markets;

- Depletion of Polish hard coal and lignite, difficult access to their resources, poor profitability of the Polish hard coal mining industry, and the economic competitiveness of hard coal imports;

- Need to modernise and replace coal-fired generation capacity due to ageing and deterioration of current installations;

- Reduced economic efficiency of electricity generated from coal (caused, inter alia, by the above-mentioned factors), combined with growing economic competitiveness of renewable energy sources (RES).

One of the most important contemporary challenges for state policy is to set the right direction for the development of the national energy sector. The responsibility of the state in this area is fundamental, and the key document defining principles for the development of the sector is Poland's energy policy [4]. The current strategic document is the Energy Policy of Poland until 2030, adopted by the Council of Ministers in 2009 [5]. Another document is the Energy Policy of Poland until 2040 [6], which contains similar objectives, but also takes into account the legislative progress that has taken place within the EU, i.e., objectives of the 2030 Climate and Energy Framework adopted by the EC in 2014, the Europe 2020 Strategy defined by the EU in 2010, the European Energy Security Strategy, and the EU Roadmap 2050. The aim is to ensure the country's energy security and to effectively plan the development of the energy sector, while taking into account emerging environmental constraints [7]. The most important strategic solution presented in this document is the so-called energy mix of the country, i.e., energy generation from various sources, including coal, gas, RES, and nuclear energy. For the first time, the strategic policy documents also mention the need to develop prosumer energy and smart grids, which is particularly important in the development of the smart village concept. The latest document that influences the country's energy policy is "Fit for 55". The "Fit for 55" package, announced in July this year, is the EU's largest initiative to reduce greenhouse gas emissions. Thanks to the implementation of these proposals, the European Union as a whole will reduce emissions by 55\% until 2030 as compared to 1990 levels, and achieve net zero emissions by 2050. The package supports greater use of energy from renewable sources, better energy efficiency, faster introduction of low-carbon modes of transport and the infrastructure and fuels that support them, and tools for the protection and development of natural carbon sinks. The implementation of most initiatives will involve additional cost of the green transformation of the EU economy in general, and energy sectors in particular. For this reason, it is pivotal to properly target the development of rural areas. The transformation of rural areas will help to avoid the need for major changes in the future, and thus enormous cost. It will contribute to the adaptation to climate change and broad environmental conservation.

The general public can perceive energy policy as follows:

- As a state action to ensure steady supply of energy;

- As new energy projects, for example, the construction of energy infrastructure;

- As environmental protection; 
- Measures to improve energy efficiency.

Energy policy can be implemented through the development of smart rural areas.

The essence of smart villages.

Smart villages are a relatively new concept [8] in European Union policy documents. The emerging concept refers to rural areas and communities taking advantage of existing development opportunities through their strengths and resources. Traditional and new networks and services are enhanced in smart villages through digital technologies, innovation, and better use of knowledge for the benefit of residents and businesses. The discussion on smart villages is related to the concept of a smart city. The development of smart cities started with the rapid advancement of technological solutions that fuelled urban growth. At the same time, it also improved the quality of life for citizens [9,10]. The smart city concept points to the widespread use of new technologies to improve the environment in a city [11,12]. Taewoo Nam and Theresa A. Pardo presented a smart city model with three dimensions: technology, people, and institutions [13,14]. A slightly broader approach treats the smart city as a new paradigm in urban development $[15,16]$, with an important role played by human and social capital, education, and the environment [17]. The environment is particularly important for the development of smart villages. The basic assumption behind the development of smart villages is the fact that rapid technological advancement, if properly targeted and linked to developing areas, creates new opportunities. It can contribute to a higher quality of services, increased income, and strengthened social potential. All of these can significantly improve the quality of life in rural areas [18]. In the case of smart villages, the focus is more on local communities taking ownership of their future, often, with the help of modern solutions. The development of smart villages is a response to the contemporary development and it is a civilization challenge. Directions for the development of smart villages are determined by processes that take place in rural areas [19] and the concept of smart growth. The development of smart villages, as a model for rural development, is also a consequence of innovative development objectives adopted by the Common Agricultural Policy in 2014-2020. Innovation in the rural sector implies the immediate and functional application of scientific advances, especially those in rapidly growing energy markets, and their adaptation to the needs of agricultural production. Innovative development in rural areas is a priority instrument promoting modern precision agriculture, vertical farming, modern business models, and the creation of sustainable value chains in areas, such as modern energy, in particular bioenergy and the circular economy. The idea of a smart village is a complement based on the use and implementation of innovative solutions, primarily to meet needs of the rural population. This concept is implemented through pilot programmes aimed at improving access to latest advances, above all, digitalisation through widespread access to broadband communications, infrastructure investment, dissemination of e-skills, benefits of human capital, revitalisation of rural areas, and efficient use of energy.

Rural areas should develop towards smart villages. However, this development should not be isolated from the development of the energy policy. Modern smart villages should be based on modern technological solutions in the energy sector. Since the concept of a smart village is new and rural areas are subject to rapid development, these areas should be subject to research. Studies are necessary to identify challenges to the smooth development of rural areas.

\section{Materials and Methods}

The analysis is based on a CATI (computer-assisted telephone interviewing) survey of the energy market and rural development experts. The experts were interviewed as part of the study. The survey involved 35 experts and was conducted in Q2 2021. The people surveyed were experts in rural development policy, smart solutions, and the energy policy. The "snowball" method was used in the study. It means that experts invited to participate in the study suggested other experts to be involved. This allowed for the selection of the most competent experts in this research area. The study identified challenges for future 
smart villages. Then, the challenges were tested and assessed in terms of their significance for inhabitants of and entrepreneurs operating in rural areas.

Individual comments helped to identify the most significant energy challenges for rural inhabitants, as well as local and state authorities. Due to the nature and limited volume of the article, the following part discusses selected results only.

\section{Results}

The study identified the following rural energy challenges:

- Low level of knowledge about new technological (energy) solutions;

- Low level of knowledge about companies that offer modern energy solutions;

- Lack of public confidence in modern energy solutions in rural areas;

- Poor willingness to cooperate;

- Lack of awareness of the environmental impact of the power industry;

- Lack of confidence in national authorities;

- Lack of confidence in local authorities;

- Lack of public awareness;

- Lack of information about financing for modern energy solutions;

- Lack of incentives for the development of modern energy solutions in rural areas;

- Shortage of experienced staff in local governments to support the rural population, including farmers;

- Lack of willingness of local communities to implement energy solutions in rural areas;

- Lack of financial capacity.

After identifying a set of obstacles to the development of modern energy solutions in rural areas, experts determined the significance of each barrier. The scale used was from 1 to 6 . A rating of 1 indicated the least important barrier, while 6 a barrier that should be urgently eliminated. Figure 1 presents the opinions expressed by experts.

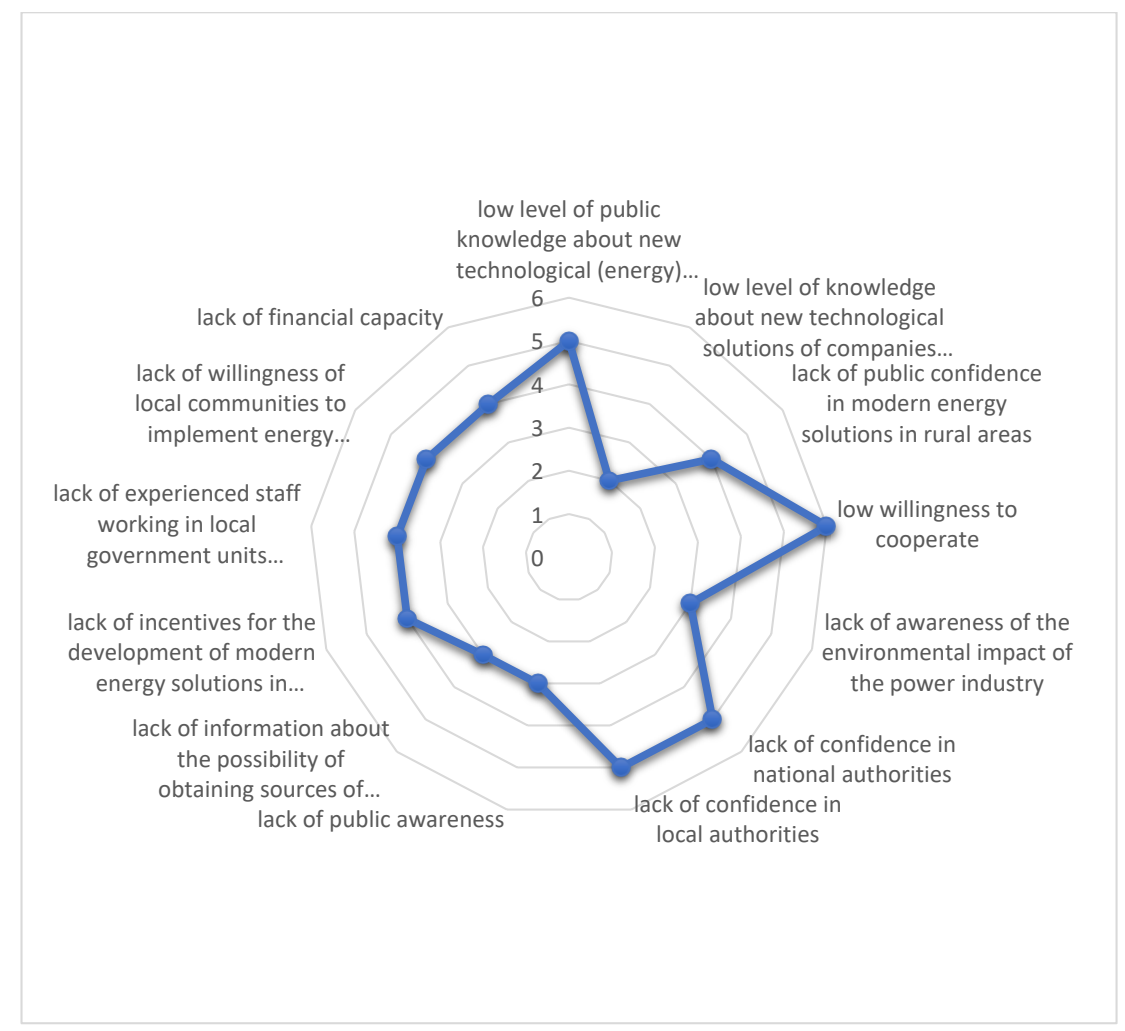

Figure 1. Importance of obstacles to the development of energy solutions in rural areas as assessed by experts. Source: own elaboration. 
According to experts, the biggest challenges confronting the development of energymodern rural areas are a lack of awareness of the environmental impact of the power industry, a low level of public knowledge about new energy solutions, and a lack of public confidence in modern energy solutions in rural areas. These are areas that particularly need to be strengthened.

These challenges were then evaluated by rural residents with no professional ties to rural areas, i.e., most often people who work in cities but only live in the countryside. The survey covered 167 rural residents. The study involved residents of the Zachodniopomorskie Province, i.e., the north-west area of Poland. The surveyed residents were between 35 and 65 years of age, and they had secondary and higher education. The results of the rating by rural residents are presented in Figure 2 .

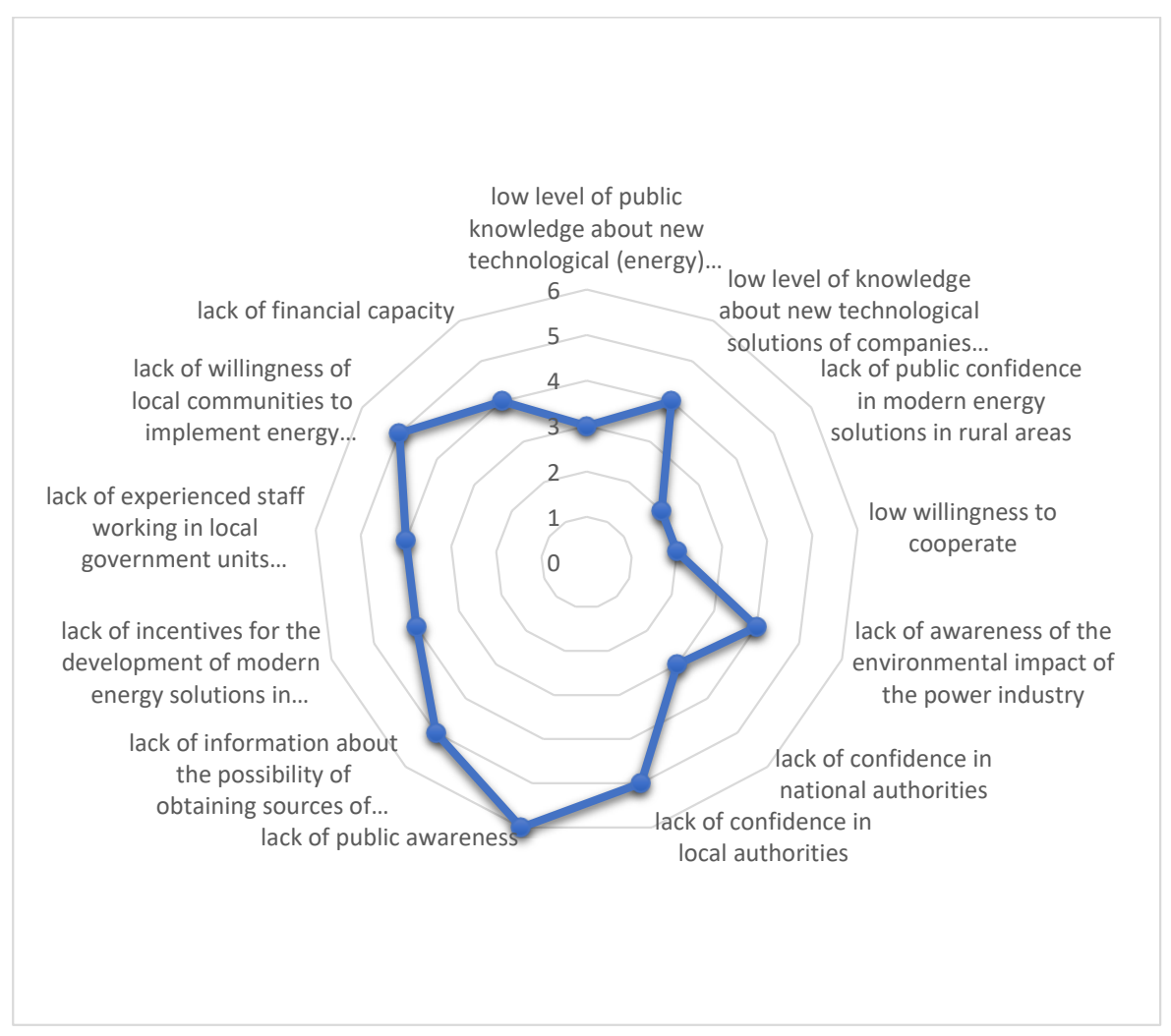

Figure 2. Relevance of challenges in energy development in rural areas as assessed by inhabitants. Source: own elaboration.

From the point of view of inhabitants of rural areas, the largest challenges include a lack of information about financing for modern energy solutions, a lack of financial capacity, and a lack of incentives for the development of modern energy solutions in rural areas.

The relevance of the energy challenges was also assessed by farmers and the results are presented in Figure 3. The survey covered 63 farmers.

From the farmers' point of view, the biggest challenges include a lack of incentives for the development of modern energy solutions in rural areas, a lack of information about financing for modern energy solutions, a lack of financial capacity, and a lack of experienced staff employed in local governments responsible for supporting society and farmers. It can be seen that these elements are inter-related, e.g., the lack of experienced staff in local governments is related to the lack of reliable information about financing.

The relevance of energy challenges was also assessed by entrepreneurs operating in rural areas and the results are presented in Figure 4. The survey covered 48 entrepreneurs. 


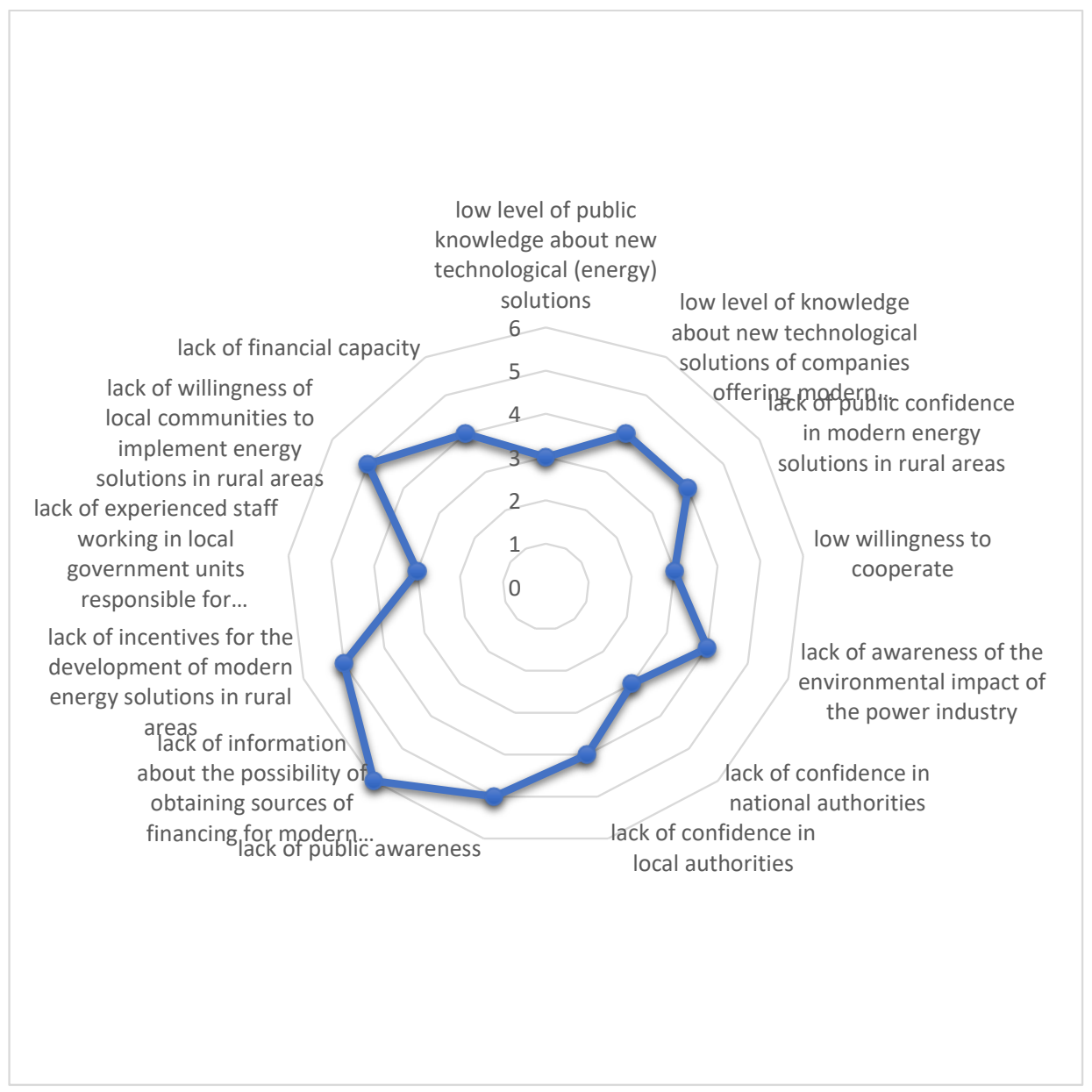

Figure 3. Relevance of challenges in energy development in rural areas as assessed by farmers. Source: own elaboration.

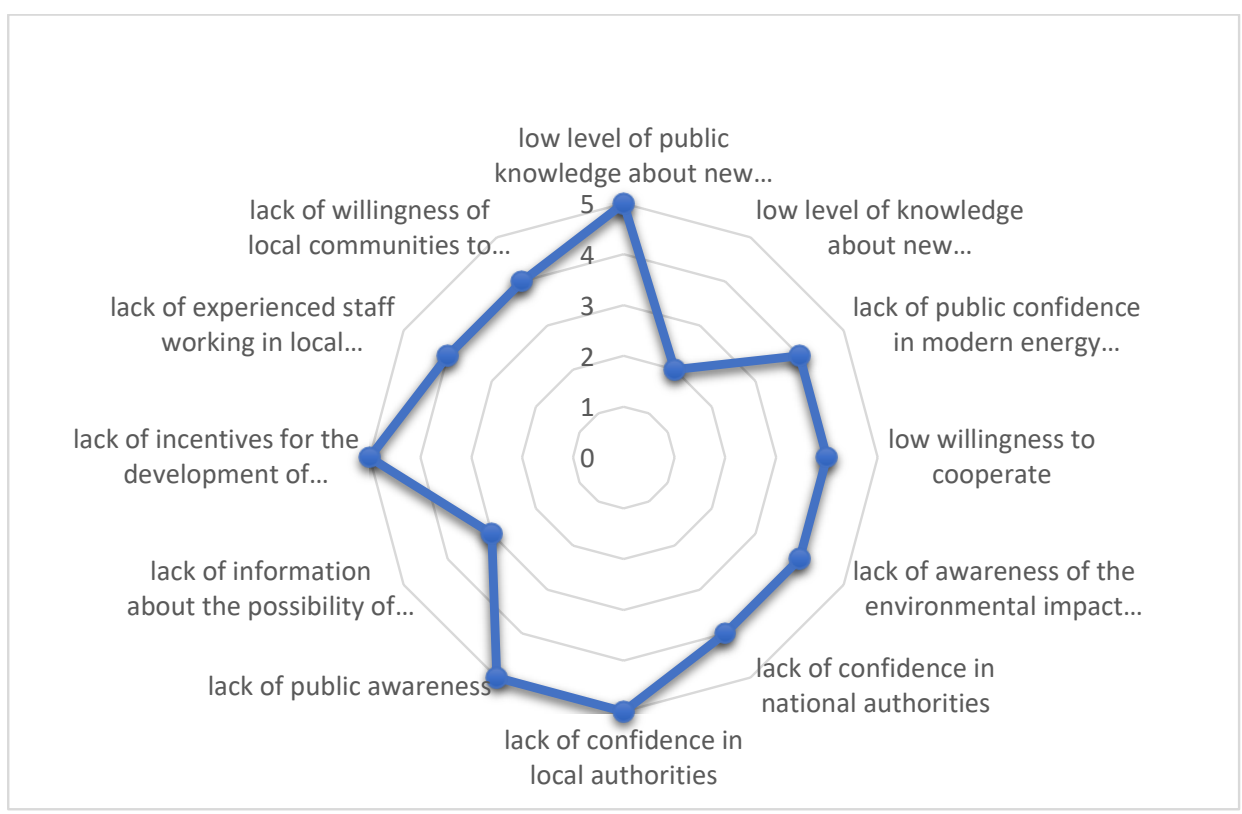

Figure 4. Relevance of challenges in energy development in rural areas as assessed by entrepreneurs. Source: own elaboration. 
From the point of view of entrepreneurs operating in rural areas, the biggest challenges include a lack of social trust to modern energy solutions in rural areas, a low level of knowledge about new technological (energy) solutions, and a lack of experienced staff employed in local government units responsible for supporting the society and farmers.

\section{Discussion: A Model for Implementing the Smart Village Concept}

According to the smart village concept, inhabitants and entrepreneurs plan the current and future development of their rural areas. In smart villages, informed, independent, and active citizens are involved in the development process. The development takes place in the following areas:

- Smart economy: competitiveness;

- Smart environment: natural resources;

- Smart people: social and human capital;

- Smart governance: participation.

A smart village is a village that uses advanced techniques and technologies to improve the quality of life. At the same time, the concept adheres to the principles of sustainable development, environmental protection, and intends to achieve the best long-term results at the lowest possible cost. In rural areas, the challenge for the power industry is to adapt to the principles of sustainable development. The concept of sustainable development can be defined as a set of targeted activities that satisfy the basic needs of inhabitants while preserving natural resources for subsequent generations [20,21]. Sustainable development of rural areas is a complex process that needs to be considered from the point of view of not only inhabitants of a given area but also the society of the whole country.

Today, environmental protection and biodiversity are particularly important in rural areas. In regard to smart village development, an important role should be attributed to sustainable energy policies related to:

- Diversification of energy sources, making maximum use of the energy stored in renewable resources in rural areas;

- Conducting large-scale promotion of RES among farmers and the rural population;

- Gradual shift in the proportion between non-renewable energy sources, mainly coal and renewable energy sources;

- Increasing popularity of distributed and prosumer energy generation that results in energy self-sufficient farms, reduction of carbon dioxide emissions in rural areas, and Poland meeting EU objectives;

- $\quad$ Promotion of energy communities based on renewable sources;

- Increased use of thermal insulation in farm buildings and households, and the renewal of rural energy grids, including farm-based installations;

- Larger role of sustainable energy use in households by emphasising sustainable energy consumption and greater use of energy-efficient appliances, also for economic reasons;

- New approach to agriculture which replaces outdated production techniques and technologies with modern solutions.

A positive image of RES can be drawn from a 2020 survey, according to which $49 \%$ of Poles believe that the use of fossil fuels, such as coal and oil, should be reduced [22]. Nevertheless, $44 \%$ of Poles still believe that Poland should use its coal resources in the power industry. According to $37 \%$ of those surveyed, coal should be the basis of the country's energy mix, and energy from RES can only be an addition part of it. It is also worth noting that every second person surveyed believes that renewable energy is expensive (51\%) and 37\% have no confidence in RES because of volatility in electricity supply due to changing weather conditions. A quarter of the interviewed Poles (26\%) are convinced that the use of renewable energy is imposed by the European Union and that mainly western companies can profit from it. 
These results are complemented by a survey implemented by Indicator [23], which shows high approval for government support to RES investment (58\%) and negligible support for coal-based generation $(8 \%)$.

In general, it bodes well for energy transition, since $78 \%$ of Poles consider RES as the best way to protect the environment and climate, $87 \%$ believe that renewable energy brings real benefits to citizens, and the majority perceive it as modern and future-oriented (82\%) in the development of modern villages, and capable to ensure the energy security of the country $(76 \%)[21]$.

Energy generated from renewable sources facilitates [24]:

- Diversification of energy sources available in rural areas;

- Creation of active prosumer attitudes, related to the use of renewable energy in the national grid;

- $\quad$ Reduced consumption of fossil fuels;

- Reasonably cheap renewable electricity;

- Significant reduction of negative environmental impacts;

- $\quad$ Reduced energy transmission cost;

- Improvement of the environmental awareness among rural communities;

- Improvement of energy supply stability in rural areas;

- Expansion of entrepreneurial attitudes among citizens.

Poland's rural areas have significant potential for renewable energy sources. At the moment, these are not fully utilised and they represent an important energy potential for farms.

The smart village concept is based on four areas: smart economy, smart environment, smart people, and smart governance, as shown in Figure 5.

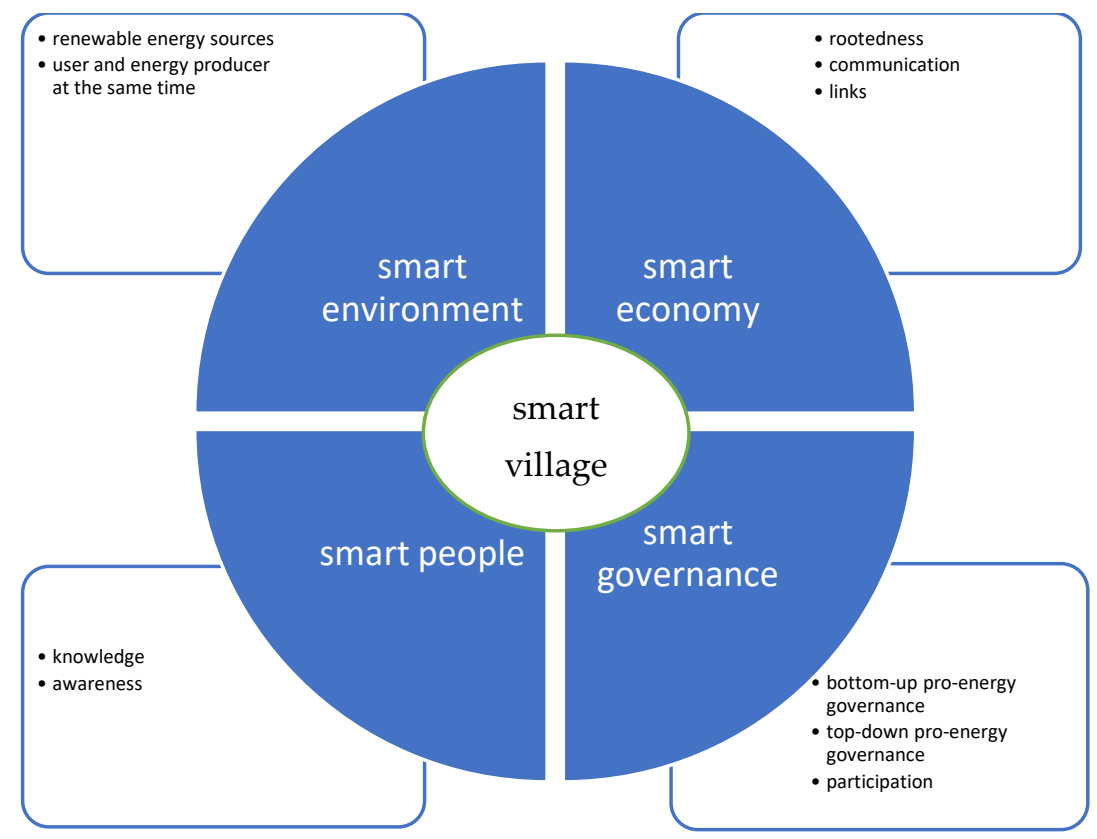

Figure 5. Smart village model. Source: own elaboration.

The development of the intelligent economy should focus on the local level. These areas can develop in conjunction with other areas, for example the development of competitiveness achieved through the use of energy innovations or through technologically advanced energy products or services. The introduction of innovations should be closely aligned with specialisations to build territorial competitive advantages [25]. Smart specialisation in rural areas [26] should highlighted in three contexts, i.e., rootedness, proximity, and connectivity. These aspects should be used to create energy communities in rural areas. 
They would deal with the generation and balancing of demand, distribution of, and trading in energy from RES or other sources within the distribution system. The energy community can be considered as a new model and the electricity market based on microgrids.

An energy community (referred to by some authors as an energy cluster [27]) contributes to energy security, supply reliability, and an adequate standard in the local area, mainly from technical, economic, and environmental points of view.

The energy transition, especially the building of energy communities, requires the involvement of different actors, including companies, local leaders, administrative units, and local inhabitants. The energy transition necessitates social solidarity, cooperation, dialogue, and local activism.

The situation of in rural areas can be improved by small local biomass or natural gas power plants, biogas, or hydropower plants and wind power plants. Unfortunately, such projects built near households will receive little acceptance among local inhabitants. Such projects contribute to regional development and improve energy security as there is no need to transport energy over long distances. This, in turn, could result in a more favourable perception of energy security among inhabitants as most of small power plant projects are located in rural areas.

Smart environment is another area related to the implementation of the smart village concept. Particular attention should be paid to the sustainable use of natural resources. We should use RES to the largest extent possible. An example of the above is the renovation of buildings to reduce their energy demand, monitor pollution, and provide modern street lighting control. This area is difficult to understand, especially for people living in the countryside who have no knowledge of the harmful effects of solutions they have been using for many years. Attention should be paid to making community members aware of the need to implement changes.

On the one hand, farms can be seen as energy users, and on the other, as producers of components for energy generation or energy itself from renewable energy sources.

Measures to ensure national energy security should be implemented with due respect to environmental conservation and the national economy. Environmental objectives set for these activities should reduce current environmental burdens, while supporting principles of sustainable development and ecological safety [28].

In marginalised areas, it is very important to prepare local communities for the use of local resources in a development-friendly way [29], while promoting the principles of sustainable development.

In regard to smart people, changes in rural areas should be promoted by inhabitants who combine their high qualifications and competencies, and creativity and ability to cooperate with the support of modern energy technologies. Thus, they should be able to continuously improve the quality of life in rural areas.

Farmers and other people in rural areas should be persuaded to use renewable energy sources to a greater extent. The use of RES has become increasingly economically viable due to the lower cost of electricity generated, increased efficiency, and improved energy security. An example is renewable energy installations. It is very important to convince farmers that they should become both consumers and producers of energy.

Energy policy in rural areas is no longer a domain of the government or energy companies. Stakeholders of the process should include the society with its needs and expectations [30].

Moreover, when we consider smart governance, transparency of activities, high quality, and availability of public services are particularly important. However, the most important is public participation, i.e., social participation. It is necessary to strengthen civic participation. In general, participation can be understood as the direct involvement of citizens in social, public, and political life [31]. The so-called "green trend" can be supportive, as it raises awareness and interest among citizens in energy production, consumption, and saving. Social participation is the active participation of the local society in local activities. It includes continuous or occasional voluntary work, and the creation of organizations, 
associations, and foundations acting for a given area. Another form of participation is individual participation, which concerns daily choices, actions, and expectations of individuals with regard to the nature and type of society he or she wishes to be part of. Individual and collective participation should be geared towards the development of modern smart villages based on modern energy solutions.

The development of all of the above areas of the smart village should be supported in the context of national security and energy independence.

\section{Conclusions}

Poland has considerable potential for the development of renewable energy sources, and the use of RES may contribute to the development of the smart village. The majority of projects based on renewable energy sources can be implemented in rural areas. Major obstacles to this development are related to difficulties in spatial planning, environmental impacts, and administrative inefficiencies. In addition, energy development requires huge investment. The development of the smart village is based on the awareness of energy efficiency and modern energy solutions. Knowledge and awareness is needed at all levels among residents, farmers, and entrepreneurs in rural areas, as well as local and national government representatives.

The introduction of technological innovations in the energy sector should take into account social conditions. In other words, we should integrate the local community context and, depending on several factors, specific positions on innovations introduced. To succeed with energy projects, social consensus is crucial. Moreover, it is important to promote an appropriate information policy aimed to increase the transparency of information. A comprehensive social education programme (knowledge and awareness building) is needed to convince local communities to the introduction of modern smart village solutions. In this context, local authorities play an important role as they provide local communities with energy-related knowledge and awareness, and encourage their social participation. Smart economy in rural areas should be based on the sense of rootedness, or the attachment to the area, and it should be transformed into a modern approach to rural areas. All this is expected to have positive effects on the intelligent environment, for example through the use of renewable energy sources, where a resident or an entrepreneur operating in a rural area becomes both a producer and a user of energy.

Author Contributions: Conceptualization, A.B.-G. and W.D.; methodology, A.B.-G. and W.D.; investigation, A.B.-G. and W.D.; writing-original draft preparation, A.B.-G. and W.D.; writing-review and editing, A.B.-G.; the CAWI method, multidimensional comparative analysis, A.B.-G. and W.D.; visualization, A.B.-G.; supervision, A.B.-G. and W.D.; project administration, A.B.-G. and W.D.; funding acquisition, A.B.-G. and W.D. All authors have read and agreed to the published version of the manuscript.

Funding: The project is financed within the framework of the programme of the Minister of Science and Higher Education entitled "Regional Excellence Initiative" in 2019-2022; project number 001/RID/2018/19; the amount of financing PLN 10,684,000.00.

Institutional Review Board Statement: Not applicable.

Informed Consent Statement: Informed consent was obtained from all subjects involved in the study.

Data Availability Statement: Not applicable.

Conflicts of Interest: The authors declare no conflict of interest.

\section{References}

1. Budziewicz-Guźlecka, A. Przekształcenia Polskiego Rynku Usług Telekomunikacyjnych; Babis, W.H., Flaga-Gieruszyńska, I.K., Eds.; Rynek usług telekomunikacyjnych: Warszawa, Poland, 2011.

2. Drożdż, W. Operator Systemu Dystrybucji W Dobie Wyzwań Innowacyjnej Energetyki; Zeszyty Naukowe Instytutu Gospodarki Surowcami Mineralnymi Polskiej Akademii Nauk: Kraków, Poland, 2018.

3. Drożdż, W. The development of electromobility in Poland. Virtual Econ. 2019, 2, 61-69. [CrossRef] 
4. Budziewicz-Guźlecka, A. Oddziaływanie Polityki Społeczno-Gospodarczej Na Zmiany Polskiego Rynku Usług Telekomunikacyjnych; Wydawnictwo Naukowe Uniwersytetu Szczecińskiego: Szczecin, Poland, 2019.

5. Polityka Energetyczna Polski Do 2030 Roku; Ministerstwo Gospodarki: Warszawa, Poland, 2009; p. 11.

6. Obwieszczenie Ministra Klimatu i Środowiska Z Dnia 2 Marca 2021 R. W Sprawie Polityki Energetycznej Państwa Do 2040 R.; Monitor Polski: Warszawa, Poland, 2021; poz. 264.

7. Drożdż, W.; Kinelski, G.; Czarnecka, M.; Wójcik-Jurkiewicz, M.; Maroušková, A.; Zych, G. Determinants of DecarbonizationHow to Realize Sustainable and Low Carbon Cities? Energies 2021, 14, 2640. [CrossRef]

8. Available online: https://ec.europa.eu/commission/presscorner/detail/pl/IP_21_(accessed on 30 November 2021).

9. Letaifa, S.B. How to strategize smart cities: Revealing the SMART model. J. Bus. Res. 2015, 68, 1414-1419. [CrossRef]

10. Budziewicz-Guźlecka, A.; Drab-Kurowska, A. The analysis of selected issues pertaining to e-administration in Poland in the context of smart city. Nord. Balt. J. Inf. Commun. Technol. 2017, 2017, 17-32.

11. Fernandes, O.E.; Meeus, L.; Leal, V.; Azevedo, I.; Delarue, E.; Glachant, J.M. Smart Cities Initiative: How to Foster A Quick Transition towards Local Sustainable Energy Systems; Final Report; European University Institute: Firenze, Italy, 2011.

12. Budziewicz-Guźlecka, A. Wybrane aspekty smart city na przykładzie Szczecina. Inform. Ekon. Uniw. Ekon. We Wrocławiu 2017, $46,20-32$

13. Nam, T.; Pardo, T.A. Smart city as urban innovation: Focusing on management, policy, and context. In Proceedings of the 5th International Conference on Theory and Practice of Electronic Governance, Tallinn, Estonia, 26-29 September 2011; pp. 185-194.

14. Nam, T.; Aldama, F.A.; Chourabi, H.; Mellouli, S.; Pardo, T.A.; Gil-Garcia, J.R.; Zheng, L. Smart cities and service integration. In Proceedings of the 12th Annual International Digital Government Research Conference: Digital Government Innovation in Challenging Times, College Park, MD, USA, 12-15 June 2011; pp. 333-334.

15. Caragliu, A.; Del Bo, C.; Nijkamp, P. Smart cities in Europe. J. Urban Technol. 2011, 18, 65-82. [CrossRef]

16. Neirotti, P.; De Marco, A.; Cagliano, A.C.; Mangano, G.; Scorrano, F. Current trends in Smart City initiatives: Some stylised facts. Cities 2014, 38, 25-36. [CrossRef]

17. Lombardi, P.; Giordano, S.; Farouh, H.; Yousef, W. Modelling the smart city performance. Innov. Eur. J. Soc. Sci. Res. 2012, 25, 137-149. [CrossRef]

18. Holmes, J.; van Gevelt, T. Energy for development-the concept. Smart Villages New Think Off Grid Communities Worldw; Heap, R.B., Ed.; Smart Villages: New Thinking for Off-Grid Communities Worldwide; Banson: Cambridge, UK, 2015; p. 13.

19. Naldi, L.; Nilsson, P.; Westlund, H.; Wixe, S. What is smart rural development? J. Rural. Stud. 2015, 40, 90-101. [CrossRef]

20. Marsden, T. The Condition of Rural Sustainability; Uitgeverij Van Gorcum: Assen, The Netherlands, 2003.

21. Bisaga, A.; Sokołowska, S. Bariery rozwoju rodzinnych gospodarstw rolnych w opinii ich właścicieli z województwa opolskiego. Studia Obsz. Wiej. 2018, 52, 157-166. [CrossRef]

22. IBRIS. Raport IBRIS-Zielony Potencjał Społeczny. Polska i Europa Środkowo-Wschodnia. 2020. Available online: https://ibris pl/2020/07/raportibris-zielony-potencjal-spoleczny-polska-i-europa-srodkowo-wschodnia/ (accessed on 26 March 2021).

23. Indicator. Badanie Opinii Polaków na Temat Różnych Źródeł Energii. 2020. Available online: https://stowarzyszeniepv.pl/2020 /05/10/badanie--opinii-polakow-na-temat-roznych-zrodel-energii/ (accessed on 6 September 2021).

24. Podhajski, K. Inwestycje w Niskoemisyjna Energetykę; NEUF: Warszawa, Poland, 2013.

25. Rodrígues-Pose, A.; Fratesi, U. Między rozwojem a polityką społeczną: Oddziaływanie europejskich funduszy strukturalnych w regionach celu 1. Studia Reg. I Lokalne 2004, 17, 5-32.

26. Wójcik, M. Koncepcja inteligentnego rozwoju (smart development)-wyzwanie dla planowania obszarów wiejskich. Acta Univ. Lodziensis. Folia Geogr. Socio Oeconomica 2018, 31, 5-15. [CrossRef]

27. Mataczyńska, E. Klastry Energii-Korzyści i Szanse Realizacji. Nowa Energia 2017, 2, 4-5.

28. Ropuszyńska-Surma, E.; Szalbierz, Z.; Węglarz, M.; Wyłomańska, A. Regionalna strategia energetyczna na bazie badań foresightowych. Rynek Energii 2011, 2, 151-156.

29. Kłodziński, M. Przedsiębiorczość pozarolnicza na wsi w procesie wielofunkcyjnego rozwoju obszarów wiejskich. Wieś I Rol. 2014, 162, 97-112.

30. de Araújo Ribeiro, A.F. Cães domesticados e os benefícios da interação. Rev. Bras. De Direito Anim. 2011, 6. [CrossRef]

31. Kaźmierczak, T. Partycypacja Publiczna: Pojęcie, Ramy Teoretyczne. In Partycypacja Publiczna: O Uczestnictwie Obywateli w Życiu Wspólnoty Lokalnej; Olech, A., Ed.; Instytut Spraw Publicznych: Warszawa, Poland, 2011. 